DOI: 10.20520/Jel-Kep.2014.4.3

\title{
Demeter Márton
}

\section{TÖBB MINT TESTŐR Hubert Dreyfus az Internetröl}

A föként Heidegger-interpretációiról (Dreyfus 1991, 2002), illetve az erős mesterséges intelligencia többszörös (Dreyfus 1972, 1979, 1992) fenomenológiai kritikájának megfogalmazójaként ismert filozófus On the Internet címü munkája szervesen illeszkedik a szerző életművébe. A diszkusszióban érvényesített terminológia, az érvényesként posztulált argumentumok, az argumentumok mögötti preszuppozíciók, és az e preszuppozíciók mögötti ágensek (ti.: a koncipiálásba bevont szerzők) együtteséből kibontható világértelmezésben ezúttal épp az Internet jelensége a fókusz. Maga a világértelmezés (mint szükségszerü szelekciók eredménye) azonban irreflexív: nem mutatja önmagát világértelmezésnek (szükségszerü szelekciók eredményének). A világértelmezés bázisáról jelenségekre fókuszáló értelemtulajdonításnak (ti.: minden megnyilvánulásnak) nem szokásos tulajdonsága a reflexivitás, azonban a filozófiai analízis igényével elöadott értekezéssel (különösen könyvterjedelmü értekezéssel) szemben a reflexivitás jogos elvárásként fogalmazható meg.

A reflexivitás iránti olvasói igény kétféleképp is kielégíthető, de mindkét megoldás előfeltételezi a reflexív hozzáállás meglétét, és a világértelmezés szelektív jellegének explicitté tételét. Az explikáció első módja a világértelmezést realizáló kulcsterminusok bevezetése (a 'bevezetés' definitív, és nem pusztán faktuális értelmében). A másik lehetőség a konkurens világnézetek (netán terminusok, argumentumok, preszuppozíciók és ágensek) elérhetővé tétele legalább a hivatkozások szintjén. A recenzens szerint Dreyfus diszkussziójában egyik megoldás sem érvényesül, és ez több okból is aggályosnak tekinthető.

Az On the Internet ugyanis még a felületes olvasás számára is nyilvánvaló módon alapvetőbb struktúrákról (ami ebben az összefüggésben annyit tesz: nagyobb filozófiai hagyománnyal rendelkező témákról) szól, mint azt a szerző a címmel sugallja, és nem egyszerüen arról van szó, hogy az Internetről tágabb kontextusban vagy analitikusabban gondolkodik, mint például egy technológiatörténeti összefoglaló. Valójában a diszkusszióban az Internet olyan empirikusan is tanulmányozható eszközként jelenik meg, amely alkalmas arra, hogy a szerző minimum 25 évszázados, és az 1950-es évek óta (sokadszor újra) különösen kurrens ismeretelméleti, etikai és ontológiai témák díszletéül szolgáljon. Ezek közül elég néhányat megemlíteni ahhoz, hogy a különösebb filozófiai müveltséggel nem rendelkező olvasó számára is nyilvánvaló legyen fundamentális jellegük: az élet értelme, a test és a lélek, az ember lényege, az emberiség jövője. A recenzens szerint ilyen kérdések diszkutálásakor nem engedhető meg az a nagyvonalúság, ahogyan a szerző a 'test', 'élet', 'ember', 'valóság' stb. terminusok jelentését a priori ismertként kezeli, miközben egy speciális értelem (minden bizonnyal Merleau-Ponty nyelvhasználata) szerint alkalmazza. ${ }^{1}$

${ }^{1}$ Ha a kortárs elmefilozófia tudomány, és van (lesz) neki története, Dreyfus eljárása mindenképp tudománytörténeti érdekesség, vagy annak fog számítani. Érdemes megfigyelni, hogy az egyébként 
A fenti kritikai megjegyzések tudatosítása mindenesetre arra inti az olvasót, hogy Dreyfus elemzéseit az explikandumok egy lehetséges olvasataként, mondhatni, fenomenológiai javaslatként vegye figyelembe, miközben tudja, hogy ugyanezen problémákhoz (már amennyire lehetséges a filozófiai problémák identifikációja) alkalmasint más eszközökkel is lehet (sőt: más eszközökkel talán szokásosabb) nyúlni. ${ }^{2}$ A kritikai attitüdöt mindazonáltal épp az olvasmány rendkivülisége (tehát: nem gyengesége) teszi különösen fontossá: az On the Internet igencsak fundamentális vállalkozás. Dreyfus nem egyszerüen az Internet (vagy az Internet-használat) kritikáját adja, hanem a test, sőt - ami a szerző észjárása szerint ugyanaz - magának az embernek a védelmében szól az olvasóhoz. Dreyfus Internet-kritikája voltaképp azokat az állításokat veszi célba, melyeket a nethasználat fanatikus propagátorai (vagy finomabban: a szélsőséges net-optimisták) oly gyakran hangoztatnak. Jelen recenzió elsősorban ezekre az állításokra, és a dreyfusi ellenvetésekre koncentrál.

\section{Néhány szó a kritika kritikájáról}

Mint minden alkalmazott, vagy legalábbis a posteriori filozófia esetében, úgy az Internet filozófiájának kapcsán is figyelembe kell vennünk, hogy az adott filozófiai felépítmény bazális struktúráit egy szúkebb vagy tágabb társadalmi (kulturális, gazdasági, politikai, technológiai) képlet keretezi. Így van ez Dreyfus Internet-filozófiájának esetében is, hiszen egy 2001-ben megjelent, majd pár évvel később másodszor is kiadott mü nem tud számot adni az azóta eltelt változásokról. Ami a filozófiai prognózisokat illeti: Dreyfus esetében is azt láthatjuk, hogy prognózisai - az azóta eltelt évek tapasztalatait figyelembe véve - inkább találgatásoknak tünnek: egy részük bevált, más részük azonban nem. Ha a filozófus el szeretné kerülni az utókornak e téves prognózisokra vonatkozó jogos kritikáját, akkor legalább két választása van. Egyfelöl megteheti, hogy egyáltalán nem bocsátkozik a jelen kritikájának extrapolációjára, vagyis egyáltalán nem él jóslatokkal: mindössze kortárs idejének deskripciójára vállalkozik. Természetesen egy mind technológiai, mint felhasználói oldalról rendkívül gyors változást mutató terület esetében ez a kortárs-idő a szokásosnál, vagy talán a kelleténél is szükebbnek mutatkozhat. Másfelől megtehető az is, hogy a filozófus kizárólag örök érvényűnek, de legalábbis tartósnak mutatkozó (tipikusan perszonális vagy

konkuráló iskolákhoz tartozó kortárs (általában analitikus hagyományú) elmefilozófusok folyamatos diszkussziót tartanak fenn egymással, miközben tipikusan nem veszik figyelembe a fenomenológiai iskola elmefilozófiai megnyilvánulásait (olyannyira, hogy erről a tényről a fenomenológusok külön megemlékeznek a Phenomenology and Philosophy of Mind címü kötetük előszavában (Woodruff Smith - Thomasson 2005:1). Dreyfus munkájában viszont mintha a teljes kortárs elmefilozófiai hagyomány (így például Searle, Minsky, Turing, Kosslyn, Smart, Armstrong, Rorty, Dennett, Rumelhart, McClelland, Pylyshyn, Smolensky, Papert, Simon, Fodor, Ryle, Kripke, Chalmers, Chomsky, Putnam, Churchland, Davidson, McDowell vagy épp Wittgenstein - aki egyébként, mint karizmatikus tanár, egyszer megemlítésre kerül) negligálódna. A dolog pikantériája, hogy a felsorolt szerzők közül több Dreyfussal együtt szerepel a Mind Design II. (Haugeland 1997) hasábjain.

2 Természetesen mint Dreyfus könyvétől, úgy egy Dreyfus könyvéről szóló recenziótól sem várható el, hogy monográfiai igénnyel értekezzen olyan hagyományos ismeretelméleti és ontológiai problémákról, mint a megértés, a tanulás vagy a megtestesülés, így az érdeklődő olvasó maga kell, hogy tájékozódjon. Mindez nem jelenti azt, hogy tájékozódásához sem kell támpontokat nyújtani: a test-lélek problémaként ismert filozófiai diszkusszióról számos monografikus igényü munka áll rendelkezésre: Beakley-Ludlow 2006., Carter 2007, Haugeland 1997, Northoff 2004, Stich-Warfield 2003, Ambrus et al 2009, vagy a fenomenológiai iskola részéről Woodruff - Thomasson 2005, illetve Gallagher - Zahavi 2008. 
társadalmi) problémákat tárgyal egy adott területre való tekintettel. Természetesen feltehető a kérdés (sőt, fel is szokták tenni), hogy vajon vannak-e egyáltalán dekontextualizálható filozófiai problémák. Jelen tanulmánynak, sőt magának Dreyfusnak sem célja az üdvözítő módszer, illetve az egyetemes problémák iránti érzékenység helyes mértékének megvitatása, itt pusztán a lehetséges ellenvetések néhány, jól meghatározható fajtáját kívántuk zárójelbe tenni, mondván, hogy erős hagyomány szól amellett, hogy a filozófia és a történeti tudományok kérdésfelvetései és problémakezelései erőteljesen különböznek egymástól. Ugyancsak egzotikumként hathat Dreyfus hozzáállása a lassan kialakulóban lévő internetkutatási hagyomány alapvetően technológiai és/vagy szociokilturális beágyazottságához képest. Ennek kiváló reprezentációját adja a 2011-ben megjelent The Handbook of Internet Studies (Consalvo - Ess 2011), melyben klasszikus filozófiai nézőpont tulajdonképpen nem is érvényesül (kivéve talán az etikával foglalkozó alfejezetet). Az Internettel kapcsolatos kutatás a kötetben voltaképp egyrészt történeti-módszertani, másrészt társadalmi-kulturális kérdésekre összpontosít, jórészt empirikus és gyakorlati problémák kapcsán, mint amilyen mondjuk az adatbiztonság vagy a pornográfia, hogy csak a két talán legnépszerübb internetkutatási témát említsük. Világos, hogy ezekhez képest Dreyfus fenomenológiai és proprioceptív megközelítése különösnek hathat.

Mindez természetesen nem jelenti azt, hogy maga Dreyfus ne igyekezne reagálni a (tágabb értelemben vett, tehát a felhasználást is magában foglaló) technológiai változásokra. Ezt mi sem mutatja jobban, mint az, hogy a 2001-es első kiadáshoz képest a 2009-ben megjelent második kiadást jelentősen átdolgozta. A második kiadás részletesebb kritikája előtt ezért néhány szóban meg kell emlékeznünk a két kiadás közötti eltérésekről, melyeket maga a szerző mutat be a második kiadás előszavában.

$\mathrm{Az}$ internetes kereséssel foglalkozó részt gyökeresen át kellett írnia, hiszen az ezredfordulós pesszimizmus helyét a Google és a Wikipedia hatalmas fejlödésével kifejezett optimizmus foglalta el a filozófus gondolkodásában.

A másik jelentős változtatás a távoktatással kapcsolatban vált szükségszerűvé. Miközben az ezredfordulón nagy reményeket füztek hozzá, az új évezred első évtizedének végére a nagy egyetemek egytől egyig feladták ilyetén tevékenységüket. Ez azonban nem nevezhető totális kudarcnak, hiszen - például a podcastok formájában - egészen másfajta oktatási mintázatok jelentek meg, melyek ugyan nem helyettesítik a kőből épült egyetemeken folyó képzéseket, de mellettük az alternatív tanulás fontos eszközeiként müködhetnek. Jelen recenzió távoktatással foglalkozó részében ezt a képet tovább árnyaljuk.

Végül, a 2009-es második kiadás kiegészült egy, a müködő virtuális valósággal foglalkozó elemzéssel a Second Life platformjának példáján keresztül. Dreyfus ide vonatkozó leírása megfelel a 2009-es állapotoknak, azonban prognózisai közül a legtöbbet azóta falszifikálta a történelem. Ez azonban nem jelenti azt, hogy filozófiai megállapításai ne lehetnének, ne lennének érvényesek vagy alkalmazhatóak más VR platformokra.

A most következő sorok tehát egy 2009-es állapotot tükröznek, egy filozófus tolmácsolásában. Jelen recenzió szerzője nem törekedett kifejezetten az azóta eltelt évek tapasztalatait beépíteni a kritikába (bár több esetben ez mégis megtörténik), hiszen ez filozófiatörténeti szempontból anakronisztikus megoldás lenne. Ugyanakkor az olvasó magában számos érvényes és érdekes megfigyelést tehet. Kezdve akár azzal, hogy a társadalmi változás üteme olyannyira felgyorsult, hogy egy 2009-es mủ ma már olvasható filozófiatörténeti beállítódással. 


\section{Merre tovább?}

Dreyfus szerint a web jövőjét illetően a legtúlzóbb kijelentések is gyakran hallhatóak, így például, hogy az Internet a gazdasági felvirágzás új korszakát hozza el, megoldja a tömegképzés problémáit, a teljes valóságot azonnal elérhetővé teszi, sőt, virtuális világokat teremt, melyekben sokkal rugalmasabb identitással lehet élni, miközben maga az élet is új értelmet nyer. A szerző azonban rámutat, hogy a sok szép szó mellett viszonylag kevés eredmény látható. A Carnegie-Mellon University kutatói azt találták, hogy amennyiben az emberek számára elérhetővé teszik a webet, inkább magányosnak és lehangoltnak érzik magukat. Egy másik kutatás szerint az internethasználat első két évében csökkent a felhasználók családtagjaikkal folytatott kommunikációja, szükült szociális körük, és növekedett lehangoltságuk, magányosságuk. A tanulmányok szerint ez az aktuális fizikai jelenlét hiányával magyarázható. ${ }^{3}$ Mindez azért történik így, mert a kommunikáló felek, ha nincsenek azonos beszédhelyzetben - sőt, egymástól igen távol vannak, - sokkal nehezebben értik meg egymást. Vagyis a megtestesülés hiánya csökkenti a kommunikáció motiváltságát, aktivitási szintjét.

\section{Hogyan keresünk az Interneten?}

Dreyfus szerint a sikeres információkeresés minden webhasználó elsődleges célja. Minden felhasználó tudja, hogy a keresőmotorok mennyit fejlődtek az elmúlt évtized során. 1999-ben sok kutató pesszimista volt az internetes keresést illetően. Ez már nem indokolt (így az internetes keresésröl szóló részt a szerző módosította a második kiadásban). 1999-ben a weboldalak hihetetlen expanziója mellett a tartalom rendezetlensége volt megfigyelhetö: praktikusan bármi bármihez linkelhető volt. A hiperlinkek nem azért kerültek alkalmazásra, mert jobban rendszerezték az információt, mint a megszokott hierarchikus struktúrák, hanem azért, mert nagyobb sebességgel képesek azt áramoltatni (a megértés vagy bármilyen, autoriter vagy megegyezéses struktúra hiányában). Azonban ha bármi bármivel összefüggésben állhat (a jelentés igénye nélkül), az nagyon megnehezíti az információkeresést. A hagyományos információs struktúrák hierarchikusan rendezettek, valamiféle klasszifikációs séma alapján. Az új információt ekkor mindig e struktúrába kell rendezni. A kereső ekkor megfelelő kategóriák szerint tud információigényéről gondoskodni. Az ilyen struktúrák használata egészen Arisztotelészig nyúlik vissza, a kategorizálás pedig tágabb és szükebb klasszifikációs osztályok meglétét feltételezi. A tanulás (és az érdeklődés) itt vertikális, a tágabb kategóriák felöl halad a szükebbek felé.

A hiperlinkes rendezés ezzel szemben horizontális: nem osztály-elem típusú relációkkal dolgozik, hanem pusztán az elemek (jelentés vagy logikai rend nélküli) összekapcsolásáról van szó. Nincsenek benne hierarchiák, minden mindennel egyazon szinten van összekötve, és

${ }^{3}$ A Carnegie-Mellon University kutatása mintha árnyaltabb képet közölne: http://www.hcii.cmu.edu/research/publications/bessiere-2008-effects-internet-use-and-s

Mindazonáltal Dreyfus is utal egy másik kutatásra: a National Public Radio felmérése (NPR) a Carnegie-Mellon és a Stanford publikációk ellenkezőjét mutatta. E szerint az emberek döntő többsége szerint az Internet és a számítógép jobbá teszi az életet: majdnem 90 százalékuk szerint a komputerek, és több mint 70 százalékuk szerint az Internet jobbá tette az életet. Ugyanakkor több mint 50 százalék nyilatkozott úgy, hogy a komputerek miatt kevesebb idő jut a családra és barátokra. Ez azt jelenti, - mondja Dreyfus - hogy ugyan látjuk a változásokat, de közben mi magunk is megváltozunk. 
a jelentés irreleváns. A klasszikus kereső-felhasználó olyan rögzült identitással rendelkező (modern) szubjektum, aki teljesebb és megbízhatóbb világképet szeretne magáévá tenni. A posztmodern hiperlink-user ezzel szemben bármely újdonságra nyitott: nem szignifikáns információkat keres, hanem a lehető legtöbb információt. Számára a meglepetés és a csodálkozás érzése fontosabb, mint a jelentés és a hasznosság. (Elsősorban filozófus és müvész) követői ezt a hierarchia és az autoritás alóli felszabadulásnak tekintik. A kapcsolatok számossága számukra fontosabb, mint azok minősége.

Amennyiben a keresőmotorok jelentésekkel nem foglalkoznak, akkor Dreyfus szerint adatbányászatról kell beszélnünk információ-keresés helyett. Sok esetben ez éppen megfelelö, például amennyiben nevekre, telefonszámokra, vagyis világos referenciával rendelkező dokumentumokra keresünk, ha azonban egy szöveg intellektuális értékét szeretnénk megtudni, ez adatbányászattal nem fog sikerülni. Ennek megoldása érdekében kezdetben humán ágensekre bízták volna a dokumentumok indexelését: ezek cédulákkal látták el a dokumentumokat, ezzel segítve a kereső ágensek dolgát. Azonban a web méretét és növekedési sebességét tekintve túl nagy ahhoz, hogy ez a módszer kivitelezhető legyen.

A korai keresőmotorok szavakból álló indexekkel dolgoztak, és a dokumentumokat a szerint osztályozták, hogy tartalmazzák-e ezeket a kifejezéseket. A szakértők szerint azonban ezekkel csak 10 százalék körüli esély van arra, hogy hasznos dokumentumra bukkanjunk. Egy ilyen szintaktikai struktúra mindazonáltal nagyon gyorsan müködtethető. A fejlesztések célja a mesterséges intelligencia használata és a természetes nyelvek jobb megértése, melyek a keresést irányíthatják. Az AI kutatások a hatvanas évek óta azon fáradoznak, hogy megoldják a következő problémát. A komputer, mint szintaktikai motor, amely csakis az input formájára vagy alakjára érzékeny, vajon hogyan viselkedhet emberhez hasonlóan, aki a szemantikára vagy a jelentésre is érzékeny? Vagyis az AI keresőmotornak úgy kellene eljárnia, mint egy embernek, aki a keresése során bizonyos oldalakat hasznosnak találna. A hatvanas években az AI kutatók még optimisták: bizonyosak abban, hogy az emberek által ismert, a világról szóló pár millió tényt képesek reprezentálni, és képesek olyan szabályokat alkotni, melyek segítségével a releváns tények fellelhetőek bármely szituáció alkalmával. Azonban a hetvenes évek végére, a nyolcvanas évek elejére világossá vált, hogy ehhez a common sense tudást is explikálni és rendszerezni kellene: ez pedig igen nagy feladat. Douglas Lenat értette meg, hogy a common sense tudás nem az enciklopédiákban van, hanem azon tudások összességét jelenti, melyeket az enciklopédia-szócikkek szerzői magától értetődőnek tartanak. Ez a háttértudás számunkra oly nyilvánvaló, hogy általában nem is tudatosul bennünk.

Általában, pusztán azért mert testtel rendelkezünk, meghatározhatatlanul sok tényt vagyunk képesek generálni testünkről, melyek közül a legtöbbet sosem teszünk explicitté. Egy AI-ágens azonban nem rendelkezik testtel, ezért minden információját adatbázisából kell merítenie. A testtel kapcsolatos információkat új helyzetre nem tudná alkalmazni. Ha megkérdeznénk, lehet-e egyszerre rágógumizni és fütyülni, akkor sem tudná megmondani, ha sokat tudna a rágózásról és a fütyülésről. Egy ember azonban mindkét tevékenységet el tudná képzelni, és mivel van teste, és van a testéről generálható tudása, meg tudná adni a választ. Azon tények száma, melyek a testtel kapcsolatos tudások explicitté tétele számára releváns, végtelen. Mi, mivel testtel rendelkezünk, bármennyi ilyen ténnyel rendelkezhetünk. Ez magyarázhatja az AI kutatások kudarcait. Testünk igen fontos ahhoz, hogy a világban jelentéseket fedezzünk fel. Ráadásul világunk is testtel rendelkező lényekkel van benépesülve: teremtményekkel, melyek kézzel és lábbal rendelkeznek, belsejük és külsejük van, egyensúlyozniuk kell a gravitációs térben, könnyebben haladnak elöre, mint hátra, fáradtak lehetnek, stb. Mindezek szükségesek ahhoz, hogy a világban jelentéseket fedezzünk fel. Elképzelhetjük, milyen elveszettek lennénk egy olyan világban, ahol szerfelett különböző testiségü lények élnének. Mindazonáltal a web növekedése kétségtelenné teszi, hogy komputeres keresőkre van szükség, melyek a mi testi jelentéstulajdonításainkat nélkülözik. 
Ezért talán nekünk kell komputer-szerü, testetlen jelentéstulajdonítási mechanizmusokat megtanulnunk. Szemantikánkat formulák közti korrelációkra kell cserélnünk. Azonban a Net jelenlegi keresőmotorjai a releváns információk mindössze 2 százalékét találják meg.

Ez volt a helyzet 1999-ben. Azóta a web növekedése nem a pesszimizmus fokozódásának, hanem az optimizmusnak lett a forrása. Terry Winograd, és Larry Page egy egészen újfajta keresési eljárást dolgoztak ki. A statisztikus adatokkal operáló keresés, illetve az AI keresőmotorok kudarcát látva olyan eljárást dolgoztak ki, amely nem kulcsszavak indexelését, és nem is a tartalom jelentésének kutatását tüzi ki célul, hanem a weboldalak hasznosságát vizsgálja. A hasznosság azt jelenti, hogy a humán ágensek, vagyis a felhasználók milyen jelentőséget tulajdonítanak az egyes oldalaknak. Rájöttek ugyanis, hogy noha a hiperlinkek praktikusan mindent összekötnek mindennel, az emberek mégis csak bizonyos oldalakra kattintanak, másokra viszont nem. Létrehoztak egy értékelő rendszert, mely a PageRank nevet viseli, és a keresések eredményeit mutatja. A PageRank egy új keresőmotort hozott létre, melynek neve Google. A Google olyan szintaktikai keresést hajt végre, amely információkat tartalmaz a humán ágensek keresési eredményiről anélkül, hogy megpróbálná megérteni a találatok jelentését. Egy weboldal fontossága ugyanis szubjektív dolog, amely az olvasók egyéni érdeklődésétől, tudásától és attitüdjeitől függ. Azonban a relatív fontosság a tényleges keresések alapján objektíve meghatározható.

\section{Távoktatás - távol, de mitől?}

Dreyfus szerint elsősorban a színvonaltól. Mint mondja, az empirikus adatokból kell kiindulni a távoktatással kapcsolatos kérdések diszkutálásakor: ekkor azt találjuk, hogy a nagy egyetemek már feladták ilyetén terveiket, és a ráfordított energiát kidobott pénznek minősítették. A szerző annak próbál utánajárni, hogy e csúfos következmények miből adódhattak.

A távoktatás gondolata már az Internet megjelenése előtt megjelent. Thomas Edison 1922-ben azt jósolta, hogy a mozgókép használata igen elterjedtté válik a képzésben, és késöbb ki is szoríthatja a tankönyveket. 1945-ben William Levenson így nyilatkozik: eljött az idő, hogy a hordozható rádió ugyanolyan megszokottá váljék az osztálytermekben, mint a tábla. Skinner pedig azt jósolta, hogy tanulógépek és programok segítségével a hallgatók kétszer olyan hatékonyan tanulhatnak, mint a hagyományos osztályokban. Napjainkban sokan a számítógépektől várják az oktatás reformját. A huszonegyedik században a világhálótól várható az oktatás revitalizálása: minden hallgató az otthonából tanulhatna, és nagyszerü tanároktól - a világ bármely pontján. Nem kellene aggódni az iskolák rossz infrastruktúrája, a tömött osztálytermek, vagy a megfizethetetlen tandíjak miatt: a kiváló képzés mindenki számára elérhetővé válhat, amennyiben képes használni az új Információs technológiákat. ${ }^{4}$

Sokan épp ellenkező véleményen vannak: a képzés személyes interakciót kíván meg, valódi tanár-diák kapcsolatot. Megkívánja emellett a szocializációt, a társas érintkezéseket, és a közös tereket is, mert mindezek együttese alapozza meg a valós tanulás tapasztalatát. A szerző szerint egyik álláspont sem rendelkezik explicit érvekkel: arra lenne szükség, hogy a

4 „Harminc év múlva a nagy egyetemi campusok már csak relikviák lesznek” - írja Peter Ducker a Forbes magazin hasábjain (id.: Don Tapscott in Nyíri 2003, 91). Kevésbé erős, de igen optimista álláspontra helyezkedik a távoktatás jövőjével kapcsolatban maga Tapscott is, igaz, még 1998-ban. Szintén lelkes írást közöl Neil Rudenstine az American Studies Journal 1996/39. számában (Nyíri 2003, 51-61), Richard L. Hannach a The Internet and Higher Education 1998. I/1. számában (Nyíri 2003,62-85) stb. Mindenesetre a Virtuális egyetem Magyarországon címü kötet szerzői (és elsősorban a szerkesztő, Nyíri Kristóf) a kilencvenes évek második felében és az új évezred első éveiben nagy reményeket tápláltak a távoktatással kapcsolatban. 
tanulás egyes állomásait elkülönítsük, és megnézzük, a távoktatás képes-e helyt állni ezeken az állomásokon.

Az első állomás az újonc szintjén található, ahol kontextusfüggetlen tudások elsajátítására van szükség. Erre példa, amikor egy gépjármü-vezetési tanfolyamon az oktató a sebességről beszél - általában. A tanulónak meg kell értenie, hogy a sebesség és a sebességmérő közt milyen összefüggés van, és hogy sebességet kell váltania az óra egy bizonyos állásánál. Az osztályteremben a tanulónak ehhez hasonló kontextusfüggetlen tudások elsajátításával kell kezdenie. Procedúrákat kell megtanulnia - ehhez nincs szükség sem osztályteremre, sem tanárra. Az Internet és egy terminál itt segítséget nyújthat. Azonban a szabálykövetés önmagában kevés haszonnal jár a való világban. Az autónál a sebességváltás nehézkes lehet, és más eljárásokat igényel hegymenetben vagy nagy súllyal megpakolva. Ugyanígy egy nyelv vagy egy tudomány megértése sokkal több, mint az elemek és a szabályok memorizálása. Nem csak tényekre van szükség, hanem azon kontextusok megértésére is, melyekben az információ értelmet nyer.

A második állomás a kezdő-haladó szintje. Mikor a tanuló valós helyzetekben kezd gyakorolni, akkor észre kell vennie, vagy egy instruktortól meg kell tanulnia, milyen releváns szituációk vagy tudásterületek esetében alkalmazható egy adott tudás. Ehhez példák kellenek, és bizonyos számú példa után a tanuló felismeri az analóg helyzeteket. Az instruktor maximákat fogalmaz meg, amelyek aztán alkalmazhatók új szituációk aspektusaira is. A szabályokkal ellentétben a maximák már előzetes tudást feltételeznek. Az autóvezetőnek a kontextusfüggetlen szabályok mellett (milyen óraállásnál váltson fel) kontextusfüggő tudással is rendelkeznie kell: ilyen például a motor hangja. A maxima így hangzik: válts fel, amikor a motor hangja egy bizonyos frekvencián szól. Ez csak tapasztalatból tanulható meg, nem lehet adekvátan megadni deskripciókkal. Az osztályteremben ugyanez a helyzet: az instruktor tanár - jelenléte itt is szükséges, de legalábbis hatásosabb, mint terminálok előtt. A tanárnak és a diáknak itt ugyanabban a közös szituációban kell lenniük.

A harmadik állomás a kompetencia szintje. A tanulónak itt több releváns szabály és maxima közül kell kiválasztania azt, ami az adott kontextusban a leginkább megfelelőnek látszik. Az autóvezető például ha úgy látja, hogy túl gyorsan halad, választhat: vagy rálép a fékre, vagy csak leveszi a lábát a gázpedálról. Ez az első állomás, ahol megjelenik a siker/kudarc felelőssége: siker esetében eufóriát, kudarc esetében elégedetlenséget érezhet. A siker és a kudarc emocionálisan csak nekünk, testtel rendelkező lényeknek fontos. A választás eredményezhet eufóriát és elkeseredést is, kimenetelétől függően. Mikor a tanuló egyre inkább emocionálisan is kötődik feladatmegoldásához, már nem kíván visszalépni a korábbi stádiumokba. De miért van szükség minderre, kérdezi Dreyfus, mikor a nyugati gondolkodás a sztoikusok, de különösen Descartes óta kifejezetten az érzelemmentes, racionalista stratégiákat részesíti előnyben? Talán azt hinnénk, hogy a belebonyolódás csak megzavarja a szabálykövetést, és irracionális döntésekhez vezet. Csakhogy ennek épp az ellenkezője igaz. Patricia Benner ápolónőket vizsgált a képességszerzés minden állomásán, és azt találta, hogy belebonyolódás, emocionális kötődés nélkül az ápolónők képtelenek képességeik fejlesztésére, általában kiégnek a sok gépies szabálykövetés következtében, és többet is hibáznak. A belebonyolódás és a kockázat kerülése általában stagnáláshoz, unalomhoz és végül regresszióhoz vezet.

A hallgatók hajlamosak utánozni a tanárt. A tanár ezért döntő szerepet játszhat abban, hogy a tanulók emocionálisan belebonyolódnak-e a tanulási helyzetbe. Ha a tanár távolságtartó és komputer-szerü, akkor a tanulók is azok lesznek. Ha azonban a tanár is belebonyolódást mutat, bátor hipotéziseket és interpretációkat nyújt, nyitott a tanulók ötleteire és kritikáira, emocionálisan is kötődik a szituációhoz, akkor a tanulók számára is emocionálisan fontossá válik a siker és a kudarc. Noha az osztályterem kevésbé kockázatos, 
mint az autópálya, azért itt is van kockázata egy idea védelmezésének vagy támadásának. Amennyiben a hallgatók egymagukban ülnek komputerük elött, akkor ez a kockázat nem lép fel. Az ilyen belebonyolódás itt lehetetlen. De még ha azt feltételezzük is, hogy egy professzor előadását a hallgatók egyszerre és online hallgatják, miközben egymás kérdéseit is hallják, akkor is elmarad a kockázat - s így a dicsőség vagy a kellemetlenség -, mégpedig az anonim részvétel miatt. A professzor helyeslő vagy elmarasztaló véleménye rendelkezik valamely emocionális hatással, de ennek ereje sokkal kisebb, mint személyes ismeretség, személyes jelenlét esetében.

A negyedik állomás a jártasság szintje, amely minden előző állomást feltételez. Ezen a szinten a teoretikus tudás helyére tapasztalati, szituációk sokaságában kipróbált tudás lép. A jártassággal rendelkező ágens minden szituációt intuitív módon is képes kezelni, de még nem tanulta meg, hogyan kell eljárni. Ez nem meglepö, hiszen sokkal kevesebb féle módja van egy szituáció szemlélésének, mint a szituációs cselekvésnek. Ezen a szinten a tanulónak még nincs elég tapasztalata ahhoz, hogy a helyzetekre adott reakciókat is elöre lássa, és automatikusan meg is valósítsa. Még mindig választások és döntések alapján fog eljárni. Az autóvezető például érzi, hogy gyorsan hajt, és választania kell, hogy fékezzen, vagy csak csökkentse a gyorsítás mértékét. A döntés meghozataláig értékes idő telik el, de kevesebb, mint a kompetens vezető esetében, aki további időt tölt el azzal, hogy tünődik a kocsi sebességén, a kanyar szögén stb. Az e szinten lévő tanuló már jól látja a megoldandó problémát, de töprengenie kell a válaszon.

Az ötödik állomás a szakértő szintje. A jártas ember már látja, mit kellene tenni, de döntenie kell, hogy azt hogyan tegyen. A szakértő azonban nem csak látja a problémát, de azonnal tudja a megoldást is. Ez különbözteti meg a jártast a szakértőtől. A szakértő vezető nem csak észleli a problémát, a nagy sebességet, de azonnal tudja, hezitálás és kalkuláció nélkül, hogy mit tegyen, és meg is teszi. A tanulás itt a szakértő tanár utánzásából áll. Az üzletemberképzés ezt jól példázza. Az analitikus-teoretikus intézmények kevés jó intuitív szakembert képeznek. A gyakorlatorientált üzletemberképző intézmények azonban esettanulmányokból, valós életbeli szituációk diszkussziójából építik fel a tanmenetet, és jobb eredményeket is érnek el. A szakértővé váláshoz azonban nem elegendő a sok esettanulmány. A repülőszimulátor is csak akkor hatásos, ha a tanuló érzi azt a stresszt és kockázatot, amely a valós vezetésre jellemző, és nem csak ül a szimulátorban. A belebonyolódás rendkívül fontos. Az üzletembernek is át kell éreznie a döntések következményeit, kockázatait, a döntéssel járó emocionális tartalmakat. Magának a testtel rendelkező individuumnak a belebonyolódására van szükség, nem csak elmejátékra - a komputeres szimulátorok csak ekkor hasznosak. A legjobb eredményt azonban gyakornoki pozíciókban lehet elérni, ahol a tanuló a megfelelő tudásterepen kell, hogy tevékenykedjen. Ha a tárgyterület tisztán elméleti, a gyakornokság akkor is szükséges. Ezért a posztdoktori képzés kutatólaborokban történik, és itt meg kell tanulni, hogy a testtelen elméleti tudás hogyan alkalmazható a valós életben. Olyan képességeket kell megtanulniuk a mesterektöl, melyekre nincsenek szabályok: meddig kell kitartani, ha a projekt nem megy jól, mennyire kell precíznek lenni bizonyos kutatási helyzetekben, stb. Ahhoz, hogy a teória a gyakorlati élettel is összeegyeztethető legyen, az ilyen gyakornokság lényegi feltétel.

Még a humán diszciplínák esetében is szükséges egy mester irányítása. A tanuló ekkor normális esetben tanársegéddé válik, és kapcsolatot tart fenn egy gyakorló tanárral. A tanár nem tud közvetlenül segíteni neki, de egyfajta problémakezelési mintát nyújt számára: hogyan kell szövegeket megbeszélni, kérdéseket feltenni stb. Például mutathat agresszív stílust, aki sosem ismeri el, ha téved, vagy receptív stílust, aki figyelembe veszi az ellenvéleményeket és képes tanulni hibáiból. Maga a tanári stílus az, amit a tanársegéd legelőször utánozni kezd, még ha ez nem is tudatosul benne. Egy inspiratív tanár, mint Wittgenstein, nem csak kérdezési stílusával, de még gesztusaival is több generációt átívelö imitátorokat teremtett. $\mathrm{E}$ 
felkészültség megszerzésének egyetlen módja a gyakornokság. Azonban rossz vágányt vesz az, aki puszta imitátorrá válik: a tanítványnak igazából arra kell rájönnie, hogyan alakíthatja ki saját egyéni stílusát. A zenészek például megtanulták, hogy egyéni mesterré az válik, aki nem egy mestert követ, hanem szekvenciálisan élete folyamán többet is megfigyel. A tanársegédnek is több tanártól kell tanulnia, a kutatónak pedig több laboratóriumban.

A hatodik, egyben utolsó állomás Dreyfus szerint a mester szintje. Megfelelő tapasztalattal szinte bárki szakértővé válhat, sőt, a túlélésért folytatott harcban valójában minden állat szakértővé válik - paradoxon, hogy egyedül az ember az, aki kockázatkerülésének következtében gyakran megragad a kompetencia szintjén. Ugyanakkor csakis ő válhat mesterré. De kiböl lesz aktuálisan is mester? Egyik magyarázat szerint abból, akinek a szakértői szint nem elégséges. Nem elég neki, amit az adott tudásterületen a szakértőtől elvárnak. Az ilyen ember nagyon erősen motivált, és olyan dolgok után kutat, amely a szakértő számára elérhetetlen, ugyanakkor vállalja a kockázatot, hogy legalább időlegesen, háttérbe szorul. A mester nem elégszik meg a megfelelö nézöpont tökéletes ismeretével - mint a megelégedett szakértő - hanem egy új perspektívát keres.

Dreyfus szerint látható, hogy az első három állomás feletti szinteken az emocionális belebonyolódás nagyon lényeges: az elszigetelt elmék legfeljebb a kompetencia szintjéig juthatnak el. Csakis emocionális, belebonyolódott, megtestesült emberi létezők válhatnak jártassá és szakértővé. Épp ezért a tanároknak is testet öltöttnek és belebonyolódásra bátorítónak kell lenniük. A gyakornokság különösen megköveteli a mesterek testi jelenlétét. Amíg a táv-jelenlét nem képes a valódi jelenlét minden aspektusát felmutatni, addig a távoktatás nem képes szakértőket és mestereket képezni. Dreyfus ebben látja a távoktatás kísérletének kudarcát.

Az azóta eltelt időszak véleményem szerint nem cáfolja, csak árnyalja a dreyfusi képet. Az utóbbi években megerősödött az alternatív oktatási technikákat és szolgáltatásokat nyújtó, online képzésre és tanulásra építő közösségek pozíciója. Ezek közül párat érdemes név szerint is megemlíteni.

Szólni kell először is a MOOC (Massive Open Online Courses) elterjedéséröl, melyben számos kiváló, elsősorban amerikai egyetem csatlakozott. A 2011-ben elindult és azóta töretlen népszerüségnek örvendő kurzusokra általában ingyenesen fel lehet iratkozni, az előadásokat online lehet meghallgatni és a vizsga szintén online tesztek és beadandók segítségével történik. A feliratkozott hallgatóknak azonban - kontroll és kockázat híján - csak elenyészően kis része teljesíti a papírszerzéshez szükséges feltételeket, ráadásul egy MMOC kurzus elvégzéséért járó papír munkaerő piaci értéke nem azonosa egy diplomáéval, miközben, természetesen lehet reális értéke (mutatja például a lehetséges munkavállaló motiváltságát, érdeklődését, tanulási vágyát, szorgalmát). Hasonló népszerüségnek örvend a Khan Academy ${ }^{5}$, mely azonban nem egyetemi, hanem magánvállalkozásként indult, illetve az MIT Open Course Ware ${ }^{6}(\mathrm{OCW})$ részben ingyenes szolgáltatásai. A fenti lelőhelyeken valóban magas színvonalú előadásokat láthatunk kitünő tanároktól, és a kurzuskínálatot böngészve azt is látjuk, hogy a kurzusok többsége kifejezetten a nagyközönségnek szóló érdekes, színes produkció. Mindazonáltal meg kell ismételni, hogy jelenleg egyik típusú online képzés sem tekinthető a klasszikus egyetemi képzések alternatívájának, pláne nem helyettesítőjének. Az online kurzusok sokkal inkább egyfajta bemutatónak, bemutatkozásnak,

\footnotetext{
5 A kurzuskínálat megtekinthető itt: https://www.khanacademy.org/

${ }^{6}$ http://ocw.mit.edu/index.htm
} 
kedvcsinálónak, illetve szórakoztató (infotainment) produkciónak tünnek, mint tudományos alapozásnak, és ennek a kategóriának feleltethető meg munkaerő piaci értékelésük is. ${ }^{7}$

\section{A test: börtön vagy ...?}

Az extropiánusok ${ }^{8}$ szerint a megtestesülés ${ }^{9}$ börtön: épp az Internet az az eszköz, amely az emberiség régi vágyát, a testi korlátok fölé emelkedést megvalósíthatja. Sőt, a test nem csak a fizikai testet és mozgásait jelenti, hanem ennél sokkal többet: hangulatainkat, melyek megszabják nekünk, hogy mi fontos és mi nem, helyünket egy adott szituációban, melyben helyt kell állnunk emberek és tárgyak között, és még számtalan más módot, mely során csalódhatunk, hibázhatunk, megsérülhetünk, sőt, meg is halhatunk. Más szavakkal, a megtestesülés véges voltunk és sérülékenységünk minden aspektusát jelenti. S valóban, ismeri el Dreyfus, ki ne vágyna arra, hogy testtelenné válva bárhová elérjen a világban, magáról másolatokat készítve pedig elkerülje a sérüléseket és a halált? Ez a vágy már Platónnál is megfogalmazódik. Azonban az extropiánusok sokkal inkább Nietzsche, mint Platón követőinek vallják magukat, mikor azt állítják, meghaladhatjuk emberi szintünket. Nietzsche azonban nem osztja a platonisták testet megvető nézetét. Szerinte ugyanis a test maga az én, a self alapja, és nem valamiféle alacsonyabb rendü létező. Az emberben pedig nem intellektusa, hanem intuitív és emocionális képességei a legfontosabbak, ezek pedig mind a test képességei. Épp ezért Nietzsche szerint az übermensch-re nem a test meghaladása, a halál és végesség legyőzése, hanem a test és a halandó volt elfogadása jellemző. A kérdés mármost a testtel kapcsolatban az, hogy vajon az az állatvilághoz láncoló, emberségünket fogva tartó, ezért legyőzendő entitás, vagy pedig, mint Nietzsche gondolja, szellemi és lelki életünk központja. Ha ez utóbbi a helyzet, akkor az Internet test-telenító jellege épp az extropiánus program Achilles-sarka. Nyitva kell hát hagyni azt a lehetőséget, hogy midőn belépünk a kibertérbe, és magunk mögött hagyjuk érzelmi, intuitív, sérülékeny, testi énünket, és ezért korábban ismeretlen szabadságra teszünk szert, ezzel egyben szükségszerüen elvesztjük néhány rendkívül fontos képességünket. Többek közt az értelemadás, a megkülönböztetés képességét, mely során elválasztjuk a relevánst az irrelevánstól; vagy a siker és a kudarc tapasztalatának komolyságát, illetve azt az igényünket, hogy a világot a lehető legjobban megragadjuk, és ezzel a dolgok realitását is értelmezni tudjuk. Ha ez a helyzet - kérdezi Dreyfus - akkor vajon mi történik, ha a Net centrális szerepet fog betölteni életünkben? Mi történik, ha ellenállhatatlan alternatív kultúrává válik? Mi lesz, ha lehetőséget ad arra, hogy egy virtuális, második életet éljünk? Vajon abban a mértékben, amennyire életünket a kibertérben éljük, olyan mértékben szuper vagy infrahumánná válunk? Vagy épp

7 Természetesen szép számmal vannak olyan kurzusok is, például a fent említett MIT online kínálatában, melyek teljes értékü megfelelöi lehetnek egy klasszikus egyetemi kurzusnak. Itt a kurzus hetenkénti bontásban tartalmazza a kötelező irodalmat és a diszkussziós témákat. Az igen bőséges kötelező irodalom (melynek jó részét meg kell rendelni például az Amazonon) elsajátítását a kurzusok sokszor előfeltételezik, s igencsak motiváltnak kell lennie annak a diáknak, aki egy online kurzusra való jelentkezés előtt egyrészt elkölt az irodalomra néhány száz dollárt, másrészt el is olvassa.

8 vö.: http://en.wikipedia.org/wiki/Extropianism

${ }^{9}$ Külön diszkussziót igényelne annak a nehézségnek az elemzése, mely az [embodiment] kifejezés értelmezéséből fakad. Az angol terminus ugyanis egyaránt fordítható megtestesülésnek, megtestesítésnek illetve megtestesültségnek. Világos, hogy (bármelyik) fordítás egyben lemond a másik kettő éppoly jogos értelmezésről, márpedig a fenti három magyar kifejezés semmiképp nem tekinthető szinonimának. Például azért sem, mert a megtestesültség állapot, a megtestesítés aktus (ágencia), a megtestesülés pedig patientia (passzívum, valaminek az elszenvedése). 
ellenkezőleg: ha elveszítjük testünket, és virtuális testekben (avatárokban) élünk, elveszíthetjük relevancia-érzékünket, tanulási képességeinket, valóságérzékünket, és a komolyság, az értelem iránti érzékelésünket? Amennyiben ez utóbbi forgatókönyv válik valóra, úgy a web-élet már nem is tünik olyan vonzónak.

A bevezetésben említett Carnegie-Mellon tanulmányhoz hasonló eredményeket hoz egy frissebb tanulmány (Stanford University). A társadalmi izoláció új hullámáról beszél, melyben egy atomizált világ képe jelenik meg emberi kapcsolatok és érzelmek nélkül. Ez meglepte a kutatókat. A Net szerelmesei szerint az Internet egyre sürübb hálóvá válik majd, melyben úgy úszkálhatunk, mint egy láthatatlan óceánban. A kérdés ez: vajon jobb lesz-e nekünk ettől? Mit nyerünk, és mit veszthetünk azzal, ha a táv-jelenlét érdekében lemondunk a szituált testi létről? A kérdés valójában kettős: egyfelől arról szól, hogyan viszonyulunk a telekommunikáción közvetített világhoz, másrészt arról, hogy miképp viszonyulunk egy ilyen világban egymáshoz?

Az olyan protézisek, mint a teleszkóp vagy a mikroszkóp, kiterjesztették a percepciót, de sokakban kétségeket támasztottak ezek megbízhatóságát tekintve. Még az 1860-as években is komolyan kétségbe vonták, hogy vajon a mikroszkóp alatt látott objektumokat az eszköz hozza-e létre, vagy valós természeti objektumokat mutat. Ugyanakkor az érzékszerveket is kezdték úgy felfogni, mint információközvetítőket a világ és az agy között. Descartes szerint a szem információkat szállít az agyhoz, az agy pedig az elméhez. Ez szerinte azt mutatja, hogy a világhoz való hozzáférésünk indirekt: a dolgok sosem látszanak direkt módon, hanem az elme és az agy reprezentációiként. Arról is beszámol, hogy sok amputált még érez végtagfájdalmat: ebből arra következtet, hogy nem lehet biztos abban, hogy saját testi fájdalma tényleg ott lép-e fel, ahol gondolja. Tehát még saját testünk sem közvetlen elérhető számunkra: direkt módon csak saját elménk tartalmaihoz van hozzáférésünk. Közvetlen hozzáférésünk nem a világhoz, hanem csakis szubjektív tapasztalatainkhoz van.

A karteziánus doktrínákra válaszul a pragmatisták (Dewey és James) azt állították, hogy a valódi kérdés a külvilággal való kapcsolatunk minemüségére irányul: vajon ez a testnélküli megfigyelőé-e, avagy a belebonyolódott megtestesült ágensé. Szerintük a kapcsolat lényege az, hogy képesek vagyunk a külső események kontrollálására, és ennek eredményeképp érzéki visszacsatolásban van részünk. Azonban ez a feedback sem elégséges ahhoz, hogy az irányítónak a valósággal való közvetlen kapcsolat érzését nyújtsa. Ha egy robotot - mondjuk egy Mars-szondát - távirányítással kontrollálunk és visszacsatolást is kapunk, ettől még a képernyőn látható kép mediáltnak tekintett, és nem a valós jelenlét érzését nyújtja. A szerző szerint a realitás-érzés kulcsa sérülékeny testünk, amely a való világban mindig veszélyeknek van kitéve: amennyiben ez a testi veszély egy táv-jelenlétben nem lép fel, úgy a valóság érzése csökken.

Merleau-Ponty szerint az embernek van egy alapszükséglete az ideális felbontásra vonatkozóan. Ha egy tárgyat szemlélünk, olyan távolságra tartjuk, hogy az egészet jól lássuk, ugyanakkor a részleteket is megfigyelhessük. Ehhez egy optimális távolság szükséges. Szerinte a test az, aminek erre az optimumra van szüksége: ez a test és a külső tárgyak koegzisztenciájának optimuma, amely nélkülözhetetlen mind a percepcióhoz, mind a motoros tevékenységekhez. A teljes táv-jelenléthez ezért Dreyfus szerint a megragadás több csatornája és ezek összehangolása szükséges. Egy jelenlét érzését adó telekonferencia például nagyfelbontású monitorokat, több nézőpontot, sokszoros feedback-et (vizuális, audil, taktilis) igényel, sőt környezeti szenzusokat (hőmérséklet, páratartalom, háttérzajok) is. A kutatók szerint mind jobban érvényesülnek a fenti tényezők, annál inkább adja a telekommunikáció a valós jelenlét tapasztalati élményét. De még ez sem elégséges. A berkeleyi robotkutatók (John Canny és Eric Paulos) kritikával illetik az ember-ember interakció csatornák szerinti (kép, hang, stb) felosztásának módszerét, és rámutatnak, hogy két ember face to face 
kommunikációja szemmozgások, fejmozgások, gesztusok és posztuláris kommunikáció összessége, és ez az interakció nagyságrendekkel gazdagabb, mint azt a legtöbb robotikus gondolja. Szerintük ezért holisztikusan kell gondolkodni, nem csatornák szerint, és a cél a megtestesült interakció modellezése. Ez pedig nem lehetséges úgy, hogy pusztán egymás mellé rendelünk 3D képeket, sztereo hangot, távirányítást és így tovább.

A fenti érvelés egészében a recenzens szerint egyértelmüen tetten érhető Dreyfus argumentációjának gyengesége, ami a test-fogalom definiálatlanságából fakad. Végeredményben arra lenne szükség, hogy a test fogalmának definiálása valamiféle utalást tartalmazzon a test határaira. Amennyiben egy ilyen határfogalom érvényesíthető (ha egyáltalán érvényesíthető), úgy a határmegvonás kérdése valóban diszkusszió tárgyává tehető. Egyáltalán nem egyértelmü ugyanis, hogy egy individuum teste voltaképpen mit takar (szó szerinti és metaforikus értelemben sem). Egészen biztosan másként gondolkodik a testről - a bevezető kritikai megjegyzésekben nevezett elmefilozófusok jó részén kívül - például McLuhan vagy Flusser.

\section{Mit keresünk mi az Interneten, avagy miféle élet egy második?}

Filozófiai szempontból Dreyfus szerint a Second Life az Internet által kínált lehetőségek közül az eddigi leginkább lenyügöző jelenség. AZ SL nem más, mint egy online 3D világ, melynek 2007-ben már több mint 11 millió „lakosa” volt, akik közül több mint félmillió napi 1 óránál többet „lakozik” ott. A lakosok kiállításokat látogatnak, virtuális javakat vásárolnak, koncertekre járnak, kiberszexuális kalandokban vesznek részt, tanulnak, beszélgetnek, ingatlant cserélnek és így tovább. A Vatikán már kitüzte célul, hogy lelkeket mentsen meg a Second Life-ban, és Svédország rendelkezik egy virtuális nagykövetséggel, melynek célja turisták toborzása. Megalkotója, Philip Rosedale, így ír a Second Life-ról: „Te határozod meg, mit jelent neked a Second Life. Szeretsz online csevegni, és találkozni velük a való világban? Légy üdvözölve. Szeretsz tervezni és ezeket a terveket valóra váltani? Légy üdvözölve. Szeretsz pénzt, valódi pénzt csinálni? Légy üdvözölve." Dreyfus szerint filozófiai szempontból több kérdés vethető fel az SL vonatkozásában, és ezek közül néhány igencsak érdekes. Először is, az SL felfogható mint üzleti vállalkozás, ugyanis az SL-ban lehet virtuális üzleteket futtatni, és ezzel valós pénzt keresni. Az SL valutája a Linden dollár (LD), melyet USA dollárra lehet váltani ( $\mathrm{kb} 260 \mathrm{LD}=1 \mathrm{USD}$ ). A Coca Cola, az IBM vagy a Toyota például már futtat Second Life üzleteket. Hogy mit hoz a jövő, még nem tudni. Frank Rose azt írja a Wired hasábjain, hogy a létrehozott avatárok több mint 85 százaléka hamar inaktívvá válik. A legjobb üzleteket az ingyen pénz és a szexuális furcsaságok ígérik: a leglátogatottabb helyek Money Island (átlag napi 136.000 látogató), ahol ingyen pénzt lehet kapni, illetve Sexy Beach (133.000 látogató/nap), ahol virtuális szexboltok, erotikus táncok és egyéb szolgáltatások találhatóak. Ezzel szemben egy átlagos napon az IBM innovációs szigetét (Innovation Island) 281, a Coke Virtual Thirst pavilonját 27 ember látogatja. Mindenesetre az, hogy a Second Life a mindennapi élethez hasonlóan profitorientált (legyen szó reális vagy virtuális javakról), filozófiailag nem túl érdekes probléma. Ugyanakkor lehet az SL-ban úgy is időzni, mint szerepjátékban, de az SL maga nem játék. A mainstream játékok struktúrával, narratívával, és problémák megoldásához szükséges cselekvésekkel vannak felruházva. Az SL-ben azonban, ahogy a való életben, nincs egy elöre meghatározott cél, nincs a sikernek és a kudarcnak egy jól meghatározott mérőrendszere. Az SL használati utasítása így ír: „teljesen rajtad múlik, hogy sikerként értékeled-e második életedet (your second life), és hogy miért értékeled úgy". $\mathrm{Az}$ is rajtad múlik, hogy mikor kezdődik és végződik ez a kalandod.

Edward Castronova szerint a virtuális világok rajongói visszavarázslatosított világokat keresnek és találnak. A terminus a Weber-féle varázstalanítás kifejezés ellentéteként értendő. A varázstalanítás a modern tudomány törekvése és következménye, és eredményeképp a 
túlvilági/másvilági erők többé már nem képezik a világ koncipiálásának részét. E szerint a tündérek, boszorkányok, démonok, angyalok és okkult jelenségek csak képzelödések. A tudomány minden dolgot képes uralni. Weber szerint a világ ilyen átalakulása egyfajta veszteség érzését kelti. Azok, akik csalódottak a természettudomány által kínált varázstalanított világban, de mégsem térnek vissza a hagyományos vallásokhoz, azok máshol keresnek vissza-varázslatosítást. A virtuális világokban megjelenő természetfeletti lények a csoda érzését adhatják vissza. Ezek az értelmezések azonban Dreyfus szerint félreértésen alapulnak, és nem tudják, hogy a varázstalanítással mi az, ami elveszett. A varázslat megtapasztalásához olyan hatalmak megtapasztalása szükséges, melyeknek autoritása van a tapasztaló felett. Ilyen erők nyilvánulnak meg a hagyományos mitológiában, de nem a programozott istenek és szándékosan kifejlesztett goblinok világában, melyek teljességgel megérthetök és irányíthatók. A csoda és a szent érzését csak akkor hozhatjuk vissza, ha nem általunk kifejlesztett, hanem minket irányító és uraló erőket tapasztalunk meg.

Az SL a fentiek mellett a müvészi teremtés egy színtereként is funkcionál: az SL lakók ruhákat, épületeket tervezhetnek, verseket írhatnak, zenéket, képeket és filmeket alkothatnak. Ezeknek egy része pontosan ugyanazon képességeket igényli, mint a való világbeli társaik. Az épületek, ruhák és szobrok kivételével ezek az SL müalkotások ugyanolyan értékü müalkotások, mintha a való világban készültek volna: mindenesetre valóságosak, és nem virtuálisak. Ezek a kreatív tevékenységek széppé varázsolják az SL világát, de semmiféle új filozófiai problémát nem vetnek fel.

Egy további, kommunikációs szempontból releváns funkció az SL-beli kapcsolatépítés. Számos olyan izolált lélek létezik, aki geográfiai vagy egészségügyi okokból nehezen köthetne személyes ismeretségeket. Ezek számára az SL remek lehetőség. Ekkor az SL tulajdonképp egy 3D chatroom, és az avatarok a beszélgetés élményét realisztikusabbá tehetik. Azonban más a célja azoknak, akik geográfiai okokból vannak távol embertársaiktól, - de azért szeretnének személyesen találkozni velük - , mint azoknak, akik kifejezetten örülnek annak, hogy mintegy maskarában, avatárok mögé bújva úgy reprezentálják magukat, amilyenek lenni szeretnének, és nem úgy, ahogy valójában kinéznek. Az SL rábízza a felhasználókra, hogy hogyan reprezentálják magukat: lehetőség van az őszinteségre éppúgy, mint a megtévesztésre. Ez különösen fontos filozófiai kérdéseket vet fel: az SL lehetőséget ad egy olyan világban való életre, amely alkalmasint érdekesebb lehet, mint a való világ. A filozófusoknak most van lehetőségük arra először, hogy részt vegyenek olyan alternatív világokban, amelyek egyszer lehetségesek voltak vagy lehetségessé válhatnak.

\section{A szórakozás egzisztencialista kritikája}

Folyamatosan nő azoknak a száma, akik több mint napi 4 órát töltenek az SL-ban, és csak akkor lépnek vissza a való világba, ha ez nagyon szükséges. Világunk hátulütői világosak, legyen szó testi vagy lelki szenvedésünkröl, végességünkről. Pascal, az első egzisztencialista gondolkodó ezt a világérzést nyomorúságnak nevezte. Az ember tudja, hogy semmit nem tehet a halál és az elkeseredettség ellen, ezért egyet tehet: nem gondol rá. Ezt az eszképista magatartást Pascal szórakozásnak (diversion= szórakozás, de eltérítést, vagy színlelt támadást is jelent) nevezte, és példaként a teniszt, a billiárdot, a szerencsejátékot vagy a vadászatot nevezte meg. Az Internet az ilyen diverzió sokkal szélesebb skáláját biztosítja. Választhatunk a szórakozás világa (amit Pascal inautentikusnak és üresnek tartott) és a szenvedésekkel, veszélyekkel teli, de jelentéssel telített világ között, amely talán olyan értelmet is rejt magában, melynek érdemes egy egész életet szentelni.

Dreyfus szerint van az SL-nak egy, a szórakoztatásnál elfogadhatóbb használata: tekinthető kalandnak is. Új médium, melynek segítségével életmódokat lehet felfedezni, és biztonságos kísérletek során a tanulásra is van lehetőség. Például lehet költekezni: a vásárlás 
az SL egyik legnépszerübb tevékenysége, és a felhasználó mindent megvehet, amit megkíván. Rosedale egy interjúban elmondta, hogy természetesen az SL kielégíti azt az alapvető vágyat, hogy a lakosok szépek, népszerüek és gazdagok legyenek benne, de ez a csoda csak az első hónapokban elegendő. Ezután a felhasználó azon kapja magát, hogy mindene megvan: de hogyan tovább? Ekkor van, aki templomot épít és meditál, vagy elkezd egy közösségért dolgozni. A SL lakosok rájönnek, hogy a fogyasztás nem teszi teljessé az életet - és ezt az SL-beli aktivitásuk során tanulták meg. Ugyanakkor konzekvenciáit tekintve az SL nem hasonlít a való világra: bármikor bárkivel meg lehet szakítani a kapcsolatot, még a saját magunkat képviselö avatárral is. Ennyiben az álarcosbálra hasonlít, ahol a maszk mögé rejtett individuum másképp viselkedhet, és tetteinek nem lesz olyan erős következménye, mint a valódi életben. Ez a kockázatmentesség jellemzi az SL-t is: egy virtuális válás után nem kell félni a másik elkeseredett arcától, vagy hogy szembe jön velünk az utcán, egy tönkrement vállalkozás után nem kell felszámolástól és csődtől rettegni. Az SL-ban egyszerüen csak tovább lehet sétálni.

\section{Az élményközösség heideggeri kritikája}

Ami Dreyfus szerint értelmet ad az életnek, amiért érdemes élni, azok a közös élmények, melyek Heidegger szerint valamilyen fókusz köré szerveződnek. A kérdés az, vajon egy virtuális valóságban létrejöhetnek-e ilyen egyén feletti közös élmények. A fillozófiai kérdést többen igyekeztek megválaszolni. A karteziánus gondolkodás szerint nem az emberek részesülnek egy közös élményben, hanem az élmények vannak (egyenként) az emberekben. Ez az élmény pedig kifejeződik és megfigyelhető az ágens testi viselkedésében, és erre más ágensek szintén testileg reagálhatnak. Ha ez a helyzet, akkor az így értett élményközösség megvalósíthatónak látszik az SL-ban: a felhasználó mondjuk úgy mozgatja az avatárját, hogy kifejezze hangulatát. Aki látja, interpretálja e mozgást, és ha helyesen interpretálja, akkor saját avatárját is a megfelelö gesztus megtételére ösztönözheti. Azonban - mint a szerző gondolja - a valós életben az élményközösség nem így müködik.

$\mathrm{Az}$ egyik érdekesség ezzel kapcsolatban az emotikonok használata, amely hivatása szerint hangulatjelként müködne. Azonban az SL esetében a sírást jelentő emotikonokat $90 \%$ ban tréfából alkalmazzák. Hogyan lehet kommunikálni, ha valaki tényleg sír? A másik fontos különbség, hogy a való életben a gesztusok és arckifejezések tipikusan spontán jönnek létre, a virtuális kommunikációban azonban választás eredményei. A dekódolás a való életben direkt, míg a virtuális kommunikációban indirekt módon történik. A virtuális kommunikáció ezért nem a mindennapi élet spontán, testet öltött direkt kommunikációjához, hanem a színész indirekt kommunikációjához hasonlít.

Dreyfus a tükörneuronok felfedezését különösen értékesnek tartja az érzelmi kommunikáció megértése szempontjából. A kutatók ugyanis olyan agyi idegsejteket találtak, melyek akkor is tüzelnek, ha valaki jelentésteli aktust végez, és akkor is, ha valaki ilyen jelentésteli aktust dekódol. Giacomo Rizzolatti szerint a tükörneuronok segítségével bepillanthatunk mások elméjébe, de nem gondolkodás vagy konceptuális következtetés, hanem érzések által. Vittorio Gallesse, a tükörneuronok felfedezője még több részletet árul el: amikor mások aktusait megfigyeljük, motoros rendszerünk a megfigyelt ágenssel rezonanciába kerül. Az aktusok megfigyelése mind az emberek, mind a majmok esetében stimuláló. A neurológiai betegségekben szenvedő páciensek vizsgálata ezt jól mutatja: az echopraxiában szenvedő demenciás betegek például sokkal impulzívabban imitálják más emberek mozgását. Az imitáció azonnal, a reflex gyorsaságával történik. Az utánzás a bevett, gyakori mozdulatokra ugyanúgy megtörténik, mint a ritka, sőt bizarr aktusoknál. Valószínüleg az egészséges ember esetében is így történik, de bennük müködik egy gátlás, 
ami tiltja a kifejezés explicitté tételét. Gallese megjegyzi, hogy ez a gátlás az ásítozás vagy olykor a nevetés esetében nem müködik.

Dreyfus szerint az élmény ugyanígy ragályos lehet: nincs szükség sem interpretációra, sem a válaszreakció tudatos megválasztására. A tükörneuronok természetesen csak akkor müködnek, ha olyan test van jelen, ami nagyon hasonlít a megfigyelö testére. A macska ásítása ránk nem ragad át. Csak empirikus kérdés, hogy egy avatár be tudja-e izzítani a tükörneuronokat. De még ha tudná is, akkor is saját avatárját tudatosan kellene rávennie, hogy az adott gesztust megtegye.

A Linden Lab programozói most egy olyan alkalmazáson dolgoznak, amely a direkt kommunikációt teszi lehetővé: egy webkamera figyelné a felhasználó arc és felsőtest mozdulatait, és ezeket realtime megjelentetné az avatárokon. Itt is marad azonban probléma. Vajon a testi kifejezések információmennyiségéből mennyi jelenik, jelenhet meg az avatáron? Az avatár teste, arca pedig különösen, teljesen emberinek kellene lennie, hogy megfelelöen vissza tudja adni ezt az információmennyiséget. Hogy ez megvalósítható-e, szintén empirikus kérdés.

Az élményközösség online megvalósulása tekintetében Dreyfus mindenesetre eléggé szkeptikus. Utal arra is, hogy Heidegger és Merleau-Ponty szerint a fókusz-esemény, amely a szekuláris világ leginkább jelentős tapasztalata, és a közös élmény elöfeltétele, négy kapacitással kell, hogy rendelkezzék: 1) közös testiség, ti.: a hangulat közvetlen testi kifejezése és közvetlen érzékelése; 2) az érzékelt hangulatok közössége, megosztása; 3) akik belebonyolódnak a fókusz eseménybe, kell hogy érzékeljék az élmény közösségét is; 4) a belebonyolódottak számára mindez mint valami tőlük független, nem-irányított kell, hogy megjelenjék. E feltételeknek Dreyfus szerint egyelöre nincs nyoma a virtuális valóságokban.

Konklúzióként Dreyfus a SL filozófiai kritikáját néhány filozófus gondolatrendszerének tükrében fogalmazza meg. Így utal arra, hogy a nietzscheiánusok jogosan tarthatják az SL-t egy maszkabálnak, ami ugyan felkínálja a kísérletezést, de a komoly kísérletek, a rizikó csak a valós világban található meg. A kierkegaardiánusok szerint a SL típusú világok ellehetetlenítik a feltétel nélküli elköteleződést, a heideggeriánusok pedig rámutathatnak, hogy az értelmes élethez szükségesek fókuszesemények, a megosztott közös élmények, és ez a jelenlegi komputergenerált világokból bizony hiányzik.

\section{Zárszó - Dreyfustól és Dreyfusról}

A szerző az On the Internet-ben voltaképp egyetlen problémát vizsgál - többféle terepen. A recenzens véleménye szerint problémakezelése - nem meglepő módon - főként a csekélyebb filozófiai hagyománnyal rendelkező vagy frissebb színtereken tud impozánsnak mutatkozni. A távoktatással vagy az SL elemzésével foglalkozó részek önmagukban is értékesnek látszanak, azonban a Dreyfus számára legfontosabb topic (durván fogalmazva: a test szerepe ember mivoltunkban) diszkutálása nem csak egyoldalú, hanem talán kissé felszínes is. Mindemellett a szerző fejtegetései még a recenzens szerint gyengébb részek esetében is olvasmányosak és szellemesek, s így kedvcsinálóként, vagy a filozófiai problémaérzékenység felszítójaként remekül funkcionálhatnak.

Végezetül érdemes kitérni a könyv zárszavára, amely akár ideológiai szónoklatként is tekinthető (sajnos nem csak a benne érvényesülö pátosz, de a nyilvánvaló csúsztatások okán is). Dreyfus a következő intelmeket címzi olvasóinak: ha képesek vagyunk elfogadni testünket, akkor a Net hasznos lehet számunkra, és képesek leszünk ellenállni a test leértékeléséből származó dichotómiáknak. Ha nem lesz fontosabb a gazdasági szempont a minőségi szempontnál a képzésben; a kockázatmentes távjelenlét a kockázatos testi interakciónál, az elkülönülés és anonimitás a valós elkötelezettségnél, az avatárok mögé bújt 
biztonságos kísérletezés a való élet testet öltött, kockázatos kísérleteinél. Az internet használata során emlékeznünk kell arra, hogy kultúránk már kétszer elveszett, elöször a platonikus, majd a keresztény kísértés következtében, mely alkalmakkor kísérlet történt sérülékeny testünkből való szabadulásra - és e kísérletek nihilizmusba torkollottak. Most ellen kell állnunk ennek a kísérletnek, nem annak ellenére, hogy a test véges és sérülékeny, hanem épp azért, mert a testünk nélkül, ahogyan Nietzsche látta, szó szerint semmik vagyunk. Eddig Dreyfus intelmei, s a recenzens kötelességének érzi, hogy újra figyelmeztessen a testlélek probléma alternatív megközelítéseire, valamint felhívja a figyelmet egy tárgyi tévedésre. A kereszténység ugyanis a korai egyháztól kezdve elítélte, sőt platonizáló eretnekségnek tekintette a testtől való szabadulás (egyébiránt gnosztikus) gondolatát, különösen szó szerinti értelemben. ${ }^{10}$

\section{IRODALOM}

Ambrus Gergely (2007) A tudat metafizikája. kognitív szeminárium. Gondolat.

Ambrus Gergely - Demeter Tamás - Forrai Gábor - Tőzsér János szerk. (2009) Elmefilozófia (szöveggyüjtemény) L'Harmattan, 2009.

Beakley-Ludlow (2006eds.) The Philosophy of Mind. Classical Problems/Contemporary Issues, 2nd ed. The MIT Press.

Carter, Matt (2007) Minds and Computers. An introduction to the philosophy of artificial intelligence. Edinburgh University Press.

Consalvo, Mia - Charles Ess (2011) The Handbook of Internet Studies. Wiley-Blackwell.

Dreyfus, Hubert (1972) What Computers Can't Do: A Critique of Artificial Reason. New York, Harper and Row.

Dreyfus, Hubert (1992) What Computers Still Can't Do. Cambridge, Mass., MIT Press.

Dreyfus, Hubert - Stuart Dreyfus (1988) Mind over Machine: the Power of Human Intuitive Expertise in the Era of the Computer. Rev.ed. New York, Free Press.

Dreyfus, Hubert (1979) From Micro-Worlds to Knowledge Representation: AI as an Impasse In: Haugeland (1997ed.): 143-182.

Dreyfus, Hubert (2009) On the Internet. Second Edition. Routledge.

Dreyfus, Hubert - Mark A. Wrathall (2006eds.) A Companion to Phenomenology and Existentialism. Blackwell.

Dreyfus, Hubert (1991) Being-in-the-world. A Commentary on Heidegger's Being and Time. Division 1. The MIT Press.

Dreyfus, Hubert (2002ed.) Heidegger Reexamined. Vol 1-4. Routledge.

Dreyfus, Hubert - Paul Rabinov (1983) Michel Foucault: Beyond Structuralism and Hermeneutics. 2nd ed. University of Chicago Press.

\footnotetext{
${ }^{10}$ Nem ennek az írásnak a feladata a test konceptusára kihegyezett dogmatörténeti vázlat prezentálása, de annyi elmondható, hogy az eretnekségek ellen hozott zsinati határozatokból és a korai keresztény szerzetesi irodalomból egyértelmúen kiderül, hogy a keresztény cél nem a test megsemmisítése vagy nyomorgatása, hanem megtisztítása és felemelése (már csak azért is, mert a keresztény ember a testi feltámadás reményét kapja).
} 
Haugeland, John (1997ed.) Mind Design II. Philosophy, Psychology, Artificial Intelligence. Revised and elarged edition. The MIT Press.

Northoff, Georg (2004) The Philosophy of the Brain. The Brain problem. Amsterdam/Philadelphia, John Benjamins Publishing Company.

Nyíri Kristóf (2003szerk.) Virtuális egyetem Magyarországon. Budapest, Typotex.

Stich, Stephen P. - Ted A. Warfield.(2003eds.) The Blackwell Guide to the Philosophy of Mind. Blackwell.

Woodruff Smith, David - Amie L. Thomasson (2005) Phenomenology and Philosophy of Mind. Oxford University Press.

Shaun Gallagher - Dan Zahavi (2008) A fenomenológiai elme. Bevezetés az elmefilozófiába és a kognitív tudományba. Győr, Lélekben Otthon Kiadó. 